Bressani, R., Elias, L. G. \& Gomez-Brenes, R. A. (1969). F. Nutr. 97, 173.

Brock, J. F. (196r). Fedn Proc. Fedn Am. Socs exp. Biol. zo, Suppl. no. 7, p. 6 r.

Brune, H., Thier, E. \& Borchert, E. (1968). Z. Tierphysiol. Tieremähr. Futtermittelk. $24,89$.

Burnett, G. S. (1 966). Br. Poult. Sci. 7, 55.

Carpenter, K. J. (1962). In Nutrition of Pigs and Poultry. Ch. 3. [J. T. Morgan and D. Lewis, editors.] London: Butterworth.

Carpenter, K. J. \& Taylor, J. H. (1968). Proc. Nutr. Soc. 27, IA.

Chaudhuri, D. K. \& Kodicek, E. (1960). Br. $\mathcal{F}$. Nutr. 14, 35.

Cromwell, G. L., Pickett, R. A. \& Beeson, W. M. (1967). F. Anim. Sci. 26, 1325.

Cromwell, G. L., Rogler, J. C., Featherston, W. R. \& Cline, T. R. (I968). Poult. Sci. 47, 840.

Doraiswamy, T. R., Subramanya Raj Uns, T. S., Venkat Rao, S., Swaminathan, M. \& Parpia, H. A. B. (1968). F. Nutr. Dietet. 5, 191.

FAO (1965). F.A.O. Nutr. Mtg Rep. Ser. no. 37.

Gounelle, H. (1969). Am. F, clin. Nutr. 22, 4.

Hadley, N. S. (rg66). Proc. High Lysine Corn Conf. (Purdue), p. i6r.

Hegsted, D. M. (1968). Am. F. clin. Nutr. 21, 688.

Hill, F. W., Anderson, D. L., Renner, R. \& Carew, L. B. (1960). Poult. Sci. 39, 573.

Howard, H. W., Monson, W. J., Bauer, C. D. \& Block, R. J. (1958). F. Nutr. 64, I5I.

Howe, E. E., Jansen, G. R. \& Anson, M. L. (1968). Am. F. clin. Nutr. 21, 523.

Howe, E. E., Jansen, G. R. \& Gilfillan, E. W. (1965). Am. F. clin. Nutr. I6, 315.

Jones, A. S., Cadenhead, A. \& Livingstone, R. M. (1968). F. Sci. Fd Agric. 19, 446.

Kakade, M. L. \& Evans, R. J. (1963). Q. Bull. Mich. St. Univ. agric. Exp Stn 46, 87.

King, K. W. (r968). Am. Y. clin. Nutr. 2x, 523.

Krehl, W. A. (1949). Vitams Horm. 7, III.

Kuppuswamy, S., Srinivasan, M. \& Subrahmanyan, V. (1958). Spec. Rep. Ser. Indian Coun. med. Res. no. 33 .

Leong, C. K., Jensen, L. S. \& McGinnis, J. (1962). Poult. Sci. 41, 36.

McLaughlan, J. M., Rogers, C. G., Chapman, D. G. \& Campbell, J. A. (1959). Can. F. Binchem. Physiol. 37, 1293.

Miller, D. S. \& Donoso, G. (1963). F. Sci. Fd Agric. 14, 345.

Mossberg, R. (1970). Proc. Nutr. Soc. 29, 39.

Patwardhan, V. N. (196r). Publs natn. Res. Coun., Wash. no. 843, p. 201.

Potter, L. M. \& Matterson, L. D. (1960). Poult. Sci. 39, $78 \mathrm{r}$.

Potter, L. M., Stutz, M. W. \& Matterson, L. D. (r965). Poult. Sci. 44, 565.

United Nations (1968). International Action to Avert the Impending Protein Crisis. New York: United Nations.

Widdowson, E. M. \& McCance, R. A. (1954). Spec. Rep. Ser, med. Res. Coun, Lond. no. 287.

\title{
The physiology of the synthesis of amino acids and their movement into the seed proteins of plants
}

\section{By B. F. Folkes, School of Biological Sciences, University of East Anglia, Norwich}

As far as is possible I have combined information derived from the work of two research groups in order to describe an idealized plant. Professor E. W. Yemm's group at Bristol, with which I was associated for over 20 years, carried out in the period I $945^{-60}$ a fairly extensive investigation of the amino acid metabolism of barley (Hordeum distichon Spratt Archer), while more recently Dr J. S. Pate and his colleagues at Belfast have provided us with a most comprehensive description of the synthesis of amino acids and carbohydrates in the field pea (Pisum arvense). Much of this work has been reviewed by Yemm \& Folkes (1958) and Pate (r 968). These two series of investigations are complementary, both because of the very different character of the plants involved and because of the use by the Bristol group of ${ }^{15} \mathrm{~N}$ as a tracer while the Belfast group used exclusively ${ }^{14} \mathrm{C}$. 


\section{Seed germination}

The first stage in the germination of the seed involves the breakdown of the seed reserves and their utilization by the growing root and shoot. In barley the stored proteins represent only about $10 \%$ of the dry weight of the grain, so that stored starch is the chief material used in respiration and for cell wall synthesis in the developing tissues. The chief storage proteins, hordein and hordenin, differ considerably in amino acid composition from the proteins which are being newly synthesized (see Table I), so that extensive interconversions of amino acids accompany the utilization of the reserves (Folkes \& Yemm, 1956, 1958). In particular glutamine and proline are used as sources of nitrogen for the new synthesis of aspartic acid, alanine, glycine, lysine and arginine. By the time some $70 \%$ of the protein reserves has been used the first leaf is generally functioning sufficiently to reverse the previous fall in total dry weight of the seedling, and it is at this stage or a little earlier that the roots start actively assimilating nitrogen from the soil (Folkes, Willis \& Yemm, 1952). Peas depart from this picture only in two respects. Proteins represent a much higher proportion of the seed dry weight so that, if the onset of leaf function is delayed by shading, the carbohydrate reserves may be exhausted and protein used as a respiratory substrate with a consequent accumulation of asparagine (see, for example, Chibnall, 1939). The amino acid composition of these proteins is much closer to that of the tissue proteins than is the case in barley, so that amino acid interconversion is less dramatic.

Table I. Amino acid composition of proteins from barley

(Nitrogen in the compound expressed as \% of protein $\mathrm{N}$ )

\begin{tabular}{|c|c|c|c|c|c|c|}
\hline \multirow{2}{*}{ Compound } & \multicolumn{4}{|c|}{ Seed proteins (Folkes \& Yemm, r956) } & \multicolumn{2}{|c|}{$\begin{array}{c}\text { Plant proteins } \\
\text { (Yemm \& Folkes, 1953) }\end{array}$} \\
\hline & Hordein & Hordenin & Globulin & Albumin & Seedling & Mature leaf \\
\hline Amide & $23 \cdot 0$ & $10 \cdot 3$ & $5 \cdot \pi$ & $5 \cdot 9$ & $4 \cdot 9$ & $4 \cdot 8$ \\
\hline Aspartic acid & $I \cdot 2$ & $4 \cdot 7$ & 5.6 & 8.0 & $6 \cdot 6$ & 6.6 \\
\hline Glutamic acid & $23 \cdot 0$ & I I $\cdot 6$ & 6.8 & $8 \cdot 7$ & $8 \cdot 0$ & $8 \cdot 2$ \\
\hline Proline & $15 \cdot 3$ & 6.6 & $2 \cdot 7$ & $4 \cdot 2$ & 3.9 & $4^{\circ} 0$ \\
\hline Glycine & $1 \cdot 7$ & $5 \cdot 2$ & 10.7 & 6.7 & 6.9 & $6 \cdot 5$ \\
\hline Alanine & $2 \cdot 2$ & $6 \cdot 6$ & 0.7 & $7 \cdot 2$ & $8 \cdot 3$ & $8 \cdot 0$ \\
\hline Valine & $3 \cdot 5$ & $4 \cdot 9$ & $4^{\cdot 1}$ & $5 \cdot 8$ & $5 \cdot 1$ & $5^{\circ} 0$ \\
\hline Leucine & 4.6 & $5 \cdot 8$ & 4.5 & 5.7 & $6 \cdot 0$ & $5 \cdot 8$ \\
\hline Isoleucine & $3 \cdot 6$ & $3 \cdot 5$ & $2 \cdot 2$ & $4^{\cdot I}$ & 4.5 & 4.7 \\
\hline Phenylalanine & $3 \cdot 6$ & 277 & $2 \cdot 1$ & 3.0 & $3^{\cdot 1}$ & $3 \cdot 2$ \\
\hline Tyrosine & $1 \cdot 6$ & $I^{-9} 9$ & $I * 5$ & $2 \cdot 7$ & $2 \cdot 3$ & $2 \cdot 2$ \\
\hline Tryptophan & 0.7 & $I \cdot I$ & 0.7 & $1 \cdot 3$ & $1 \cdot 9$ & $1 \cdot 8$ \\
\hline Serine & $3 \cdot 2$ & $4^{\cdot 2}$ & $3 \cdot 9$ & $4 \cdot I$ & $3 \cdot 5$ & $3 \cdot 3$ \\
\hline Threonine & $1 \cdot 9$ & $3 \cdot 1$ & $2 \cdot 4$ & 3.4 & $4^{\circ} \circ$ & $4 \cdot 0$ \\
\hline Cystine & $\mathrm{I} \cdot 5$ & 0.9 & $2 \cdot 6$ & $1 \cdot 5$ & 0.9 & 0.9 \\
\hline Methionine & 0.8 & $\mathbf{I} \cdot \mathbf{I}$ & 0.9 & $1 \cdot 4$ & $I \cdot 2$ & I'3 \\
\hline Lysine & 0.8 & $4 \cdot 8$ & $6 \cdot 3$ & $7 \cdot 9$ & $7 \cdot 9$ & $6 \cdot 5$ \\
\hline Histidine & $2 \cdot 2$ & $4 \cdot 3$ & $3 \cdot 1$ & $4 \cdot 3$ & $4 \cdot 2$ & 4.0 \\
\hline Arginine & 6 & 12 & 22 & 13 & 15 & 15 \\
\hline Unknown & -0.4 & $4 \cdot 7$ & $12 \cdot 1$ & $I \cdot I$ & $\mathrm{I} \cdot 8$ & $4 \cdot 2$ \\
\hline
\end{tabular}


Assimilation of nitrogen and the synthesis of amino acids in roots

The initiation of nitrogen assimilation in roots appears to be dependent upon an adequate carbohydrate supply and is usually associated with the beginning of carbohydrate export by the first leaf. The patterns of ${ }^{15} \mathrm{~N}$ incorporation into the amino acids of plant roots (Yemm \& Willis, 1956; Cocking \& Yemm, I96r) are closely similar to those observed for food yeast by Sims \& Folkes (1964); in this latter instance it has been clearly established that glutamic acid is the first amino acid synthesized from inorganic nitrogen, all other amino acids being derived from this primary product, so that it seems likely that the same is true for higher plants. The enzyme responsible for this primary assimilation, an NADP-linked glutamate dehydrogenase, is found both in yeast and in plant roots (Sims, Folkes \& Bussey, 1968). It is subject to both inhibition and repression by high levels of amino acids, so it seems possible that the onset of assimilation may have to wait until the level of amino acids derived from the seed stores has been sufficiently depleted by growth to allow synthesis and functioning of the enzyme. This may explain why active assimilation starts earlier in barley than in field pea.

When labelled ammonia is supplied to the roots of young barley plants the ${ }^{15} \mathrm{~N}$ is rapidly incorporated into all of the free amino acids and into the amino acid residues of the root protein (Cocking \& Yemm, I96r). Some amino acids are produced in excess of the requirements of protein synthesis and so tend to accumulate in the free amino acid pool; these include glutamine, asparagine, glutamic acid, alanine and arginine. When similar experiments are carried out on detached roots, rapid incorporation into and accumulation of glutamine is a conspicuous feature (Yemm \& Willis, 1956), since under these conditions little synthesis of protein occurs. In field pea the pattern of synthesis is similar to that in barley but asparagine and aspartic acid are here relatively more important, so that they together with glutamine and homoserine are the chief nitrogenous components exported from the root in the transpiration stream (Pate, 1968). This export represents the chief nutritional role of the root, one that can be sustained only because of the downward flow from the leaves of carbohydrates from which the carbon skeletons of the amino acids are derived.

\section{The synthesis of nutrients in leaves}

The young leaf is entirely dependent upon nutrients passing into it from the seed stores or from older leaves. Later, as it starts to photosynthesize, the products of carbon assimilation are built largely into its own structure, so that it is only as nearly full size is attained that export of photosynthetic products begins (Pate, 1968). Chief among these is sucrose, but reducing sugars and amino acids are also present. Of the amino acids, some may be re-exports of components of the transpiration stream, since there is a tendency for the greatest volume of sap to flow into those leaves which are most nearly mature, and hence need least amino acids for growth. Other amino acids however can be shown to be true products of leaf metabolism, since they are heavily enriched with ${ }^{14} \mathrm{C}$ if labelled $\mathrm{CO}_{2}$ is supplied to the leaf. Included here are glycine, serine and alanine. It is noteworthy that just as 
yeast, a heterotrophic organism, can serve as a useful model for root metabolism so can a unicellular autotrophic alga such as Chlorella for leaf metabolism. The kinetics of ${ }^{14} \mathrm{C}$ and ${ }^{15} \mathrm{~N}$ incorporation into amino acids of Chlorella have been studied with some precision by Bassham \& Kirk (r964); their results suggest that glycine, serine and alanine are synthesized within the chloroplasts themselves using carbon directly fixed in photosynthesis. The amino nitrogen for these syntheses derives partly from outside the chloroplast, and it seems likely that in the leaves of higher plants glutamine and asparagine from the transpiration stream may be the chief source, the amide nitrogen being also used by being converted into glutamic acid by the NAD-linked glutamate dehydrogenase found in leaves. This enzyme, whose synthesis in yeast is actually induced by amino acids, is much less susceptible to feedback inhibition than is the NADP-linked root enzyme (Sims et al. 1968) and consequently it is able to function in the presence of fairly high concentrations of amino acids. Even so, the rate of amino acid accumulation on a sunny day is often so high that the phloem system is unable to translocate immediately all the products of photosynthesis. Just as, in such circumstances, excess carbohydrate is commonly converted into starch which can later be carried away during the hours of darkness, so amino acids are temporarily made into proteins; quite large diurnal fluctuations in leaf protein content have been described by Carr \& Pate (I967), nitrate reductase being one of the proteins which is regularly synthesized and later degraded. In my own view the fact that this particular enzyme shows a diurnal rhythm need not have any specific significance; it may just be that the messenger RNA for this protein is commonly present in leaves for quite another reason, and that this together with the messages for other proteins are merely exploited to synthesize a temporary protein store. Similar diurnal changes in a number of other enzymes have been observed in marram grass by A. P. Sims \& G. R. Stewart (private communication).

An interesting feature of the leaf export system as revealed by Pate (I966) is the way in which the direction of flow changes. In young plants with only a few leaves the products of photosynthesis from an individual leaf pass both downwards to the roots and upward to the growing shoot. Later as the plant grows more leaves, the flow becomes polarized, probably because the direction of phloem transport is under concentration control (Mason \& Maskell, 1928) and a high zone for photosynthesis products is built up in the mid region of the plant, with low zones or sinks in the roots and stem apex. Consequently lower leaves export only to the roots and upper leaves only to the short apex. This in turn has made it possible to investigate the relative contributions made to the shoot apex by the root and shoot. When lower leaves are supplied with labelled $\mathrm{CO}_{2}$ the photosynthetic products pass first to the roots, but later the amino acids of the shoot apex become labelled, a major proportion of the radioactivity in the cellular proteins being found in glutamyl and aspartyl residues, proline, lysine and arginine. With label supplied to upper leaves these residues contain a much smaller proportion of the activity, and instead the leucines, histidine, phenylalanine, serine, glycine, alanine and valine become more highly labelled. Only some of these amino acids are directly supplied by the 
leaves and the remainder are made in the shoot apex from carbohydrates derived from the leaves and from the nitrogen in the transpiration stream.

\section{Interaction between root and shoot}

From this it can be seen that roots and leaves play complementary and interdependent roles in the nutrition of the shoot apex. Under normal conditions the primary assimilation of nitrogen takes place in the root, using carbohydrate produced by the leaves as a carbon source. Some of the assimilated nitrogen will be used for the synthesis of amino acids required for root growth but the majority will be exported, chiefly in the form of amides (glutamine predominating in barley and asparagine in the field pea) although other amino acids such as proline, lysine and arginine are also important. The leaves are chiefly involved in the photosynthesis of carbohydrates, which are their major export, but in addition they make the majority of amino acids needed for their own growth, using the amides derived from the root as chief nitrogen source. A few amino acids, including especially serine, glycine, alanine and the leucines, are produced in excess by direct photosynthesis in the chloroplast, and are exported both to the shoot apex and, to a lesser extent, to the root to supplement endogenous production. A further export will be amino acids passed from the root in the transpiration stream and concentrated in the leaf, from which they will be translocated by the diffusion-regulated phloem system. Within the shoot apex itself many amino acids will be synthesized directly, using carbohydrate from the leaves and amides from the roots, but other amino acids derived from root or leaves will also be incorporated unchanged into the shoot proteins.

We still know remarkably little about how the balance between the various organs is maintained. Presumably a major factor in this will be control of the level and activity of individual enzymes, such as those involving the glutamate dehydrogenases which have already been cited. Taking these as examples we can deduce that the synthesis and export of a particular amino acid by one organ may result in high enough concentrations of that amino acid in another organ to repress the formation there of the enzymes catalysing the same synthesis, or at least to inhibit their activity if they have already been formed. A consequence of this is to reinforce still further the division of labour between organs and their interdependence on one another.

The tenuous nature of this balance is apparent from the phenomenon outlined by Pate ( 1968 ). When large amounts of nitrate are supplied to the roots of field pea the roots gradually cease to synthesize amino acids and the leaves take over amino acid production for the plant. Presumably here the series of events is as follows. The roots take up nitrate in such concentrations that they cannot use all of it, so that the excess passes to the leaves in the transpiration stream (Wallace \& Pate, 1965). Here an active nitrate reductase is induced which converts the nitrate into ammonia in high enough concentrations to allow efficient glutamic acid synthesis by the NAD-linked glutamate dehydrogenase (this enzyme has a high $\mathrm{K}_{\mathrm{m}}$ for ammonia compared with the NADP-linked system and so can function only where 
ammonia level is high (Sims et al. r968)). The resulting production of amino acids will both decrease the quantity of carbohydrate available for export to the roots and increase the amino acid export, thus inhibiting the root glutamate system and increasing still further the flow of nitrate to the leaves.

\section{Seed production and leaf senescence}

Flowering and seed production are other factors which tend to disturb the normal balance between the organs, since the developing seeds represent a major sink for carbohydrates and amino acids which diverts the flow of these away from the roots and leaves. Depletion of the cellular amino acid pools upsets the balance between protein synthesis and degradation so that protein breakdown predominates and the resulting amino acids are moved out of the senescent leaf and into the seeds. In the field pea this movement is extremely localized, each leaf supplying virtually all its products to the flower or flowers arising at the same node (Pate, I968). In barley, on the other hand, the morphology of the plant leads to a general upward flow of nutrients in which the oldest leaf is the first to die, and senescence occurs progressively in each leaf in turn and finally in the awns (Yemm, I949). This phenomenon of progressive leaf senescence can often be observed long before the onset of flowering, since under conditions of limited nitrogen supply the protein of the oldest leaf is broken down to provide amino acids for the growth of younger leaves.

The relationship between protein degradation in the leaves and protein synthesis in the developing seeds can probably best be discussed with regard to barley. As already noted, the chief storage proteins of barley have amino acid compositions which differ markedly from that of the leaf protein, and this is particularly true for the hordein where over $60 \%$ of the total nitrogen of the protein is associated with just two kinds of amino acid residue: glutamine and proline. At first sight then one might assume that extensive amino acid interconversions occur here, just as they do when the process is reversed in seed germination. In fact, however, it is by no means certain that this is true although the information is admittedly much more sketchy than that for germination. Two facts serve to cast some doubt on the assumption. Firstly the salt-soluble proteins of the seed, the albumin and globulin fractions, have a much more balanced amino acid composition (see Table r), and in lownitrogen barleys an appreciable amount of the grain's total nitrogen is found in these proteins. Secondly, at least under conditions of good nitrogen supply, quite large amounts of nitrogen are still being assimilated by the roots during the phase in which the seed proteins are being laid down, so that the amino acids available to the seed include not only those derived from the leaf proteins but also those made in the root. Some of the results of Yemm (1949) are based upon the crop which yielded the 'high nitrogen' barley later analysed by Folkes \& Yemm (1958), and from his Figure 3 it is clear that up to $33 \%$ of the seed amino acids probably originated from new assimilation rather than from the leaf proteins. This observation can be combined with the seed analysis to give an amino acid balance sheet for seed protein formation (Table 2); in this I have calculated the amino acid content of the seed proteins and the contribution made to this by the leaf proteins, so that the 
Table 2. Amino acid balance sheet for the formation of seed proteins

\begin{tabular}{|c|c|c|c|}
\hline \multirow[b]{2}{*}{ Compound } & \multicolumn{3}{|c|}{ Total or amino acid $N$ (mg/roo grains) } \\
\hline & $\begin{array}{l}\text { Associated with } \\
\text { the seed proteins }\end{array}$ & $\begin{array}{c}\text { Derived from } \\
\text { breakdown of leaf } \\
\text { proteins }\end{array}$ & $\begin{array}{c}\text { Difference: } \\
\text { estimate of that } \\
\text { derived from newly } \\
\text { assimilated } \mathrm{N}\end{array}$ \\
\hline Amide & $15 \cdot 6$ & $3 \cdot 2$ & $12 \cdot 4$ \\
\hline Aspartic acid & $3 \cdot 9$ & $4 \cdot 5$ & -0.6 \\
\hline Glutamic acid & $16 \cdot 7$ & $5 \cdot 6$ & I I I I \\
\hline Proline & $10 \cdot 5$ & $2 \cdot 7$ & $7 \cdot 8$ \\
\hline Glycine & $4 * 3$ & $4 \cdot 4$ & -0.1 \\
\hline Alanine & 4.4 & $5 \cdot 4$ & $-1 \cdot 0$ \\
\hline Valine & $5 \cdot I$ & 3.4 & $1 \cdot 7$ \\
\hline Leucine & $5 \cdot 8$ & $3 \cdot 9$ & $I \cdot 9$ \\
\hline Isoleucine & $3 \cdot 7$ & $3 \cdot 2$ & 0.5 \\
\hline Phenylalanine & $3 \cdot 3$ & $2 \cdot 2$ & $I \cdot I$ \\
\hline Tyrosine & $2 \cdot 2$ & $\mathrm{I} \cdot 5$ & 0.7 \\
\hline Tryptophan & $1 \cdot 0$ & $1 \cdot 2$ & -0.2 \\
\hline Serine & $3 \cdot 7$ & $2 \cdot 2$ & I.5 \\
\hline 'Threonine & $2 \cdot 7$ & $2 \cdot 7$ & - \\
\hline Cystine & $1 \cdot 6$ & 0.6 & $I \cdot O$ \\
\hline Methionine & $X \cdot I$ & 0.9 & $0 \cdot 2$ \\
\hline Lysine & $3 \cdot 9$ & $4 \cdot 4$ & -0.5 \\
\hline Histidine & $3 \cdot 3$ & $2 \cdot 7$ & 0.6 \\
\hline Arginine & 10.2 & $10 \cdot 2$ & $\cdots$ \\
\hline Total N & 103 & 68 & 35 \\
\hline
\end{tabular}

difference can be assumed to represent the contribution made by the newly assimilated nitrogen. About $90 \%$ of it is apparently made up of glutamine and proline, typical products of root activity, while the only other significant components are small amounts of leucine, serine, valine and phenylalanine, which could well have arisen by photosynthetic interconversion of glutamine in the few leaves which were still functional.

All of this is undoubtedly an oversimplification, since some glutamine is likely to be produced by protein catabolism in senescent leaves (see Yemm, 1949; but his values based on detached dark-kept leaves are likely to be far too high an estimate of this), while amino acids other than glutamine and proline are probably exported by the roots (see, for example, the analysis of bleeding sap from Hordeum vulgare by Wallace \& Pate, 1967). However, despite this it seems likely that there is virtually no amino acid interconversion within the developing seed, but instead the amino acids received from the rest of the plant are incorporated unchanged into the protein stores. As soon as this is recognized then the biological significance of proteins as unbalanced as hordein becomes clearer; hordein synthesis may well be a way of utilizing the amino acids (chiefly glutamine) arising from the roots at a time when the main mass of amino acids derived from the leaf proteins is being used up in the synthesis of hordenin and the salt-soluble proteins. Since this root assimilation is likely to be greatest under conditions of high nitrogen, this could easily explain what has long been known, namely that hordein levels increase disproportionately as the nitrogen content of the grain increases (Bishop, 1928; Urion \& Golovtchenko, 
1940), the salt-soluble proteins becoming proportionately less important, while hordenin remains in fairly constant ratio to the total stored protein. Although the methods used in both of these investigations overestimate the hordenin content (see Folkes \& Yemm, r958), the general statement is nonetheless true. In seedlings with a low nitrogen supply on the other hand, the soil nitrogen is likely to be largely exhausted before the onset of flowering and the reduced availability of ront amino acids will result in a substantially lowered hordein content.

In making these conjectures I have, of course, offered no suggestions as to how the relative rates of synthesis of the various seed proteins might be regulated. In this regard it seems possible that little is necessary in the way of complex cellular machinery in order to obtain the result I have outlined. Provided that there are approximately equal amounts of the messenger RNAs for hordein and hordenin available in the cell, it can be shown for a simple model system that control could rest upon the relative availability of the different amino acid-transfer RNA complexes, the concentrations of which will presumably reflect the levels of the individual free amino acids. If a few amino acids are particularly abundant in the cell, then the synthesis will be favoured of those proteins which contain the highest proportions of those amino acid residues. Thus, provided the various seed proteins differ sufficiently in their composition, the incorporation of amino acids into the storage proteins will tend to reflect amino acid availability.

\section{The production of seed with improved protein content}

It is worth re-emphasizing at this stage the paucity of real information about the processes controlling the synthesis of storage proteins. In the foregoing pages I have put forward a possible explanation which is supported by only the slightest of circumstantial evidence. So in going on to discuss the implications of this hypothesis I am entering deep into speculation.

If the thesis is correct, that storage protein synthesis depends upon amino acid supply, then there will be several levels at which improvement in the amino acid content of the seed might be achieved. At the physiological level, increasing nitrogen supply to the root, while leading to an increased protein content in the grain, clearly encourages the formation of the poorly balanced hordein. What though, one wonders, would be the effect of supplying the nitrogen direct to the leaves as a foliar spray of ammonia or urea? It might be that much less glutamine would be formed than if the nitrogen were assimilated by the root system (cf. the amino acid pattern of Xanthium pennsylvanicum, a plant with no root nitrate reductase (Wallace \& Pate, I967)).

At the genetic level there are already varietal differences which might be exploited; thus crude hordenin content, while a fairly constant proportion of the total nitrogen of the grain, differs between about $30 \%$ and $40 \%$ in different varieties. I have been unable to trace any work which offers a physiological explanation for these differences, but varied patterns of growth and hence the exploitation of soil nitrogen, or alternatively variations in the control properties of some of the enzymes synthesizing amino acids in the root, might lead to differences in amino acid export from the root 
which would affect the relative amounts of synthesis of the various proteins.

Even more basically, it is difficult to predict what would be the effects of deletion or modification of, for example, the hordein gene. Could it be that glutamine and other amino acids would then accumulate to a point at which natural feedback mechanisms would take over and allow amino acid interconversions to occur in younger leaves and awns, or even in the seed itself, so that amino acid supply came to match more nearly the new requirements of the seed? From a knowledge of the complexity of most biological systems one would guess that some such regulatory mechanism as this would operate, but it is clear that we need much more knowledge about the physiology of amino acids during seed formation before we are able to offer a rationale for the breeding of high nutritive varieties.

I wish to thank Dr A. P. Sims for his helpful criticism of the manuscript.

\title{
REFERENCES
}

Bassham, J. A. \& Kirk, M. (1964). Biochim. biophys. Acta 9o, 553.

Bishop, L. R. (1928). F. Inst. Brewing 34, ror.

Carr, D. J. \& Pate, J. S. (1967). Symp. Soc. exp. Biol. 21, 459.

Chibnall, A. C. (1939). Protein Metabolism in the Plant. Yale: University Press.

Cocking, E. C. \& Yemm, E. W. (1961). New Phytol. 6o, 103.

Folkes, B. F., Willis, A. J. \& Yemm, E. W. (1952). New Phytol. 51, 317.

Folkes, B. F. \& Yemm, E. W. (1956). Biochem.7. 62, 4.

Folkes, B. F. \& Yemm, E. W. (1958). New Phytol. 57, 106.

Mason, T. G. \& Maskell, E. I. (1928). Ann. Bot. 42, 571.

Pate, J. S. (1966). Ann. Bot. N.S. 30, 93.

Pate, J. S. (1968). In Recent Aspects of Nitrogen Metabolism p. 219. [E. J. Hewitt and C. V. Cutting, editors.] London: Academic Press Inc.

Sims, A. P. \& Folkes, B. F. (1964). Proc. R. Soc. B r59, 479.

Sims, A. P., Folkes, B. F. \& Bussey, A. H. (I968). In Recent Aspects of Nitrogen Metabolism p. 9I. [E. J. Hewitt and C. V. Cutting, editors.] London: Academic Press Inc.

Urion, E. \& Golovtchenko, V. (1940). Bull. Soc. chim biol., Paris 22, 203.

Wallace, W. \& Pate, J. S. (1965). Ann. Bot. NS 29, 655.

Wallace, W. \& Pate, J. S. (1967). Ann. Bot. NS 3r, 2 I3.

Yemm, E. W. (1949). New Phytol. 48, 3 I5.

Yemm, E. W. \& Folkes, B. F. (1953). Biochem. F. 55, 700.

Yemm, E. W. \& Folkes, B. F. (1958). A. Rev. Pl. Physiol. 9, 245.

Yemm, E. W. \& Willis, A. J. (I956). New Phytol. 55, 229.

\section{The breeding of wheat and maize with improved nutritional value}

\author{
By V. A. Johnson, P. J. MAtTern and J. W. Schmidt, Agricultural Research Service, \\ US Department of Agriculture and Department of Agronomy, University of Nebraska, \\ Lincoln, Nebraska, USA
}

Cereal grains are a basic food for much of the world's population. They are equally important as animal feed in countries in which livestock is produced. All cereal grains lack the balance of essential amino acids needed for full utilization of their protein. The amino acid lysine is in the shortest supply in the cereals. 